\title{
SCREEN PARASITE
}

\author{
Paolo Tiausas \\ Ateneo de Manila University \\ ptiausas@ateneo.edu
}

\begin{abstract}
About the Author
Paolo Tiausas graduated with a BFA in Creative Writing from Ateneo de Manila University as a recipient of both the Loyola Schools Awards for the Arts and the Joseph Mulry Award for Literary Excellence. He was a fellow for poetry in the 11th Ateneo National Writers Workshop in 2012 and the 14th IYAS National Writers Workshop in 2014. His poems have appeared in Kritika Kultura, Likhaan: The Journal of Contemporary Philippine Literature, Heights, Softblow, Plural: Online Prose Journal, and The Philippines Free Press. He was shortlisted for the Purita Kalaw Ledesma Prize for Art Criticism in the 2015 Ateneo Art Awards, and was an awardee of the Carlos Palanca Memorial Awards for Literature in 2016. He is currently teaching in the Department of Fine Arts of ADMU.
\end{abstract}




\section{A HISTORY OF SLEEP}

The living area is comfortable.

Until two in the morning

the bulbs flicker as they please.

They whisper. They hear.

You cannot tear away from dreaming

alcohol claims and the necklace braids

a snake. All is fair

with the television running

a film. She's apparently surrounded.

Hero, tell us, how will you whine?

Whose name appears on this line?

Who teaches you to sleep like this.

The room. The dark. The witness.

The house a ritual of malice and comfort.

Exhibit A: a woman, on the couch, alone. Wrong.

Weren't you a traitor from sleep? From within?

How many knocks? One-two-three. See?

Excuse me is anybody home in

this mansion of a - and ma-

let me in. 


\section{DARK EXPERIMENTS}

What parts merge the mirror and road? The rain drops its awakening, water traversing some white line parting the middle of the street. Cars move.

The road is empty. A few cars

enter one eye then leave the other.

Hesitation, who thinks

the hesitations blossoming in your wake?

Ex. the bus toppling over on the third avenue.

The passengers turn into butterflies, set fire on blue, a few seconds glitter then ash.

I will admit I sleep with my left eye open and waiting for the dream.

In the night the body is chained to the bed with keys in plain sight from the window

offering this room to those who seek home. Wings flap in dead evening and a piece of my life lands as dust on skin.

Sudden cold. Who mutes the rain?

Why so? I recognize that gait.

Railroad tracks break from eye to object and upon the retina, everything is depth.

The one door in the room does not budge. Eye of the horn and eye of the engine.

Eye of the beloved. Approaching. 


\section{LIBRARY}

Letters on the page turn insect-shaped despite having recognized, I recognize

the filthy skin of that which I read, a lump in my throat and I feign sleep.

I guess it's my mother searching as she strays into this room.

The slipper's sole on floor, slow breathing sudden cough —-whoever's

cough - focus breaks upon

the sound of a coin, creak, a crash.

Who is my mother anyway? At midnight this logic slants slightly.

Shut eyes survey these surroundings, deeper into the gray of eyelids

I search for my mother, or any mother, this machinery aims for every corner

as these thousand visions melt simultaneously. These thousand words appear simultaneously.

Only then do thousands of minuscule legs land on my lips. I cough and I spit

as a housefly then lands, on the mouth, on the lips of a woman I find in a room. 


\section{SCREEN}

The excavating eye

aligns with me in the jeep. Digs

the phone from his pocket.

Hands investigate

then bring it close to the eye.

Close enough to kiss

the eye with material with flesh

of the message asking

is he going home. A wild guess

as like an icepick he starts

gouging his vision with light.

Tinkering with machines

and a mechanic's metal engine.

What is the depth

of his actions, what is depth

as I return to the jeep ride

the loud horn clinging to me

tightly, a steel covering

but the ride is quick, deceives

my vision. The light

scatters. There is no home 
in transit nor quantity.

The landscape a soft puddle minus

the man adjacent quietly his eyes

attached, whole, policing

person and cellphone, light and black

of the eyes, senses racing ahead

the road ahead of him then me. 